\title{
Cytogenetic and radiation hybrid mapping of the bovine interleukin 4 induced 1 (IL4I1) gene to cattle chromosome 18 (Brief Report)*
}

\section{Zytogenetische und Radiation-Hybrid-Kartierung des bovinen Interleukin 4 Induced 1 (IL4I1) Gens auf Rinderchromosom 18}

(Brief Report)

\section{ALBRECHT RIEF ${ }^{1}$, MANFRED SCHWERIN ${ }^{1}$ and TOM GOLDAMMER ${ }^{2}$}

${ }^{1}$ Research Group Functional Genome Analysis and ${ }^{2}$ Research Unit Molecular Biology, Research Institute for the Biology of Farm Animals, Dummerstorf, Germany

\section{Background}

The interleukin 4 induced 1 (IL4I1) gene, also known as FIG1, encodes a lysosomal protein in B cells with L-amino oxidase (EC 1.4.3.2) property and a high preference for aromatic amino acid substrates implicating a fundamental role in antigene processing and presentation (MANSON et al. 2004). In human, IL4I1 has been assigned to chromosome 19q13.3-19q13.4, a hot spot for susceptibility to several autoimmune diseases (CHAVAN et al. 2002). Based on comparative genome data between human and cattle (GOLDAMMER et al. 2002), an assignment of IL4l1 to Bos taurus chromosome 18 (BTA18) has been predicted within a quantitative trait locus for somatic cell score (KÜHN et al. 2003). This prediction is supported by the putative bovine sequence for IL4I1, LOC520692, which has been assigned to BTA18 close to 56.1 megabases within the annotated bovine sequence (NCBI build Btau-4.0). Therefore, we started positional cloning of bovine IL4I1, as a candidate gene related to adaptive immunity, i.e. during udder infections in cattle. Here we present the physical assignment of the bovine IL4I1 gene by fluorescence in situ hybridization (FISH) and radiation hybrid (RH) mapping.

\section{Material and methods}

The primer sequences IL4I1-F 5'-CCA TCGCGTACC GACTTT-3' and IL4I1-R $5^{\prime}$-ACT TGA CTG CCG TCT CCA C-3' have been designed from the putative IL4I1 sequence LOC520692 (GenBank acc. no. XR_028168) and have been used for RH mapping in a bovine 5000 rad RH panel (WOMACK et al. 1997). A BLAST search within the NCBI genome database (http://www.ncbi.nlm.nih.gov) identified the ovine BAC clone $\mathrm{CH} 243-207017$ as genomic DNA sequence corresponding partially to bovine IL4I1. This BAC from CHORI library CH243 (http://bacpac.chori.org) has been used for FISH in cattle. Amplification of IL4I1 specific DNA within the BAC by PCR has been performed at an annealing temperature of $58^{\circ} \mathrm{C}$ using the described primers. Automated sequencing of the $216 \mathrm{bp}$ long amplicon followed by a BLAST search with the resulting DNA sequence within the NCBI genome database showed $95 \%$ similarity between the bovine and ovine sequences for IL4/1. 
GOLDAMMER et al. $(2002,2009)$ describe further methodical steps such as PCR, preparation of the BAC DNA as probe for FISH, cytogenetic procedures for preparation of bovine metaphase chromosomes, the hybridization procedure and probe visualization in more detail. The position of IL4/1 in the ILTX-2005 RH map (EVERTS-VAN DER WIND et al. 2005) has been calculated with the software Carthagene 1.0R (DE GIVRY et al. 2005).

\section{Results}

The BAC CH243-207017, containing the IL4I1 gene, has been used as probe for FISH and was assigned to BTA18q25-q26 (Figure 1). PCR with the IL4I1 primers in the $\mathrm{RH}_{5000}$ panel resulted in a retention frequency of 0.13 . The data vector obtained was 0000000010 0000001001000000100000001001000000000000000000000100001000000010010000 0000010010 ( $1=$ present in cell line; $0=$ not present in cell line). Two-point linkage analysis connected IL4I1 with a LOD score of 8.8 in a distance of $26.5 \mathrm{CR}_{5000}$ to RH marker BF440193 (map position $596\left(\mathrm{CR}_{5000}\right)$. Our data confirm the predicted gene sequence position for the bovine IL4I1 alias sequence LOC520692 and anchor the corresponding genome region (NCBI component acc. no. AAFC03010410) to BTA18q25-q26.
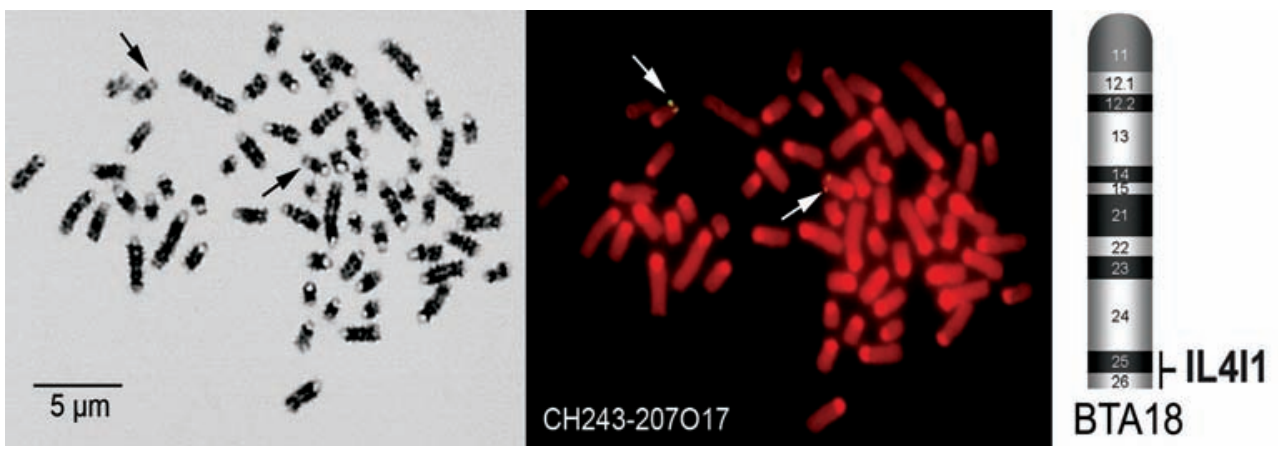

Figure 1

Assignment of IL4I1 to cattle chromosome 18q25-q26

Kartierung des Gens IL4I1 auf Rinderchromosom 18q25-q26

\section{Acknowledgements}

We thank Jim Womack (Texas A\&M University, TX, USA) for providing the RH panel and Harris Lewin and Annelie Everts-van der Wind (University of Illinois, IL, USA) for providing the $\mathrm{RH}$ marker raw data set of the ILTX-2005. Funds for this work came from DFG (GO896/6-3), BMBF, and FBF (Förderverein Biotechnologieforschung e.V., AZ 0313381).

\section{References}

Chavan SS, Tian W, Hsueh K, Jawaheer D, Gregersen PK, Chu CC (2002) Characterization of the human homolog of the IL-4 induced gene-1 (Fig). Biochim Biophys Acta 1576, 70-80

De Givry S, Bouchez M, Chabrier P, Milan D, Schiex T (2005) CARHTA GENE: multipopulation integrated genetic and radiation hybrid mapping. Bioinformatics $21,1703-4$ 
Everts-van der Wind A, Larkin DM, Green CA, Elliott JS, Olmstead CA, Chiu R, Schein JE, Marra MA, Womack JE, Lewin HA (2005) A high-resolution whole-genome cattle-human comparative map reveals details of mammalian chromosome evolution. Proc Natl Acad Sci USA 102, 18526-31

Goldammer T, Brunner RM, Rebl A, Wu CH, Nomura K, Hadfield T, Maddox JF, Cockett NE (2009) Cytogenetic anchoring of radiation hybrid and virtual maps of sheep chromosome $\mathrm{X}$ and comparison of X chromosomes in sheep, cattle, and human. Chromosome Res [accepted]

Goldammer T, Kata SR, Brunner RM, Dorroch U, Sanftleben H, Schwerin M, Womack JE (2002) A comparative radiation hybrid map of bovine chromosome 18 and homologous chromosomes in human and mice. Proc Natl Acad Sci USA 99, 2106-11

Kühn C, Bennewitz J, Reinsch N, Xu N, Thomsen H, Looft C, Brockmann GA, Schwerin M, Weimann C, Hiendleder S, Erhardt G, Medjugorac I, Förster M, Brenig B, Reinhardt F, Reents R, Russ I, Averdunk G, Blümel J, Kalm E (2003) Quantitative trait loci mapping of functional traits in the German Holstein cattle population. J Dairy Sci 86, 360-8

Manson JM, Naidu MD, Barcia M, Porti D, Chavan SS, Chu CC (2004) IL-4-Induced Gene-1 is a Leukocyte L-Amino acid oxidase with an unusual acidic $\mathrm{pH}$ preference and lysosomal localization. J Immuniol $173,4561-7$

Womack JE, Johnson JS, Owens EK, Rexroad CE'II, Schläpfer J, Yang YP (1997) A whole-genome radiation hybrid panel for bovine gene mapping. Mamm Genome 8, 854-6

Received 6 March, accepted 4 May 2009.

Corresponding author:

Dr. TOM GOLDAMMER

email: tomgoldammer@fbn-dummerstorf.de

Research Unit Molecular Biology, Research Institute for the Biology of Farm Animals (FBN), Wilhelm-StahlAllee 2, 18196 Dummerstorf, Germany 